\begin{tabular}{|c|c|c|}
\hline 1 & $\begin{array}{l}\text { International Journal of Research in Engineering and Innovation } \\
\text { (IJREI) } \\
\text { journal home page: http://www.ijrei.com }\end{array}$ & 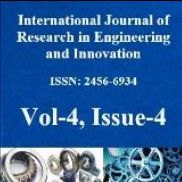 \\
\hline & ISSN (Online): 2456-6934 & 40 \\
\hline
\end{tabular}

\title{
Study of self-compacting concrete using recycled waste concrete as coarse aggregate
}

\author{
Mohd Aiyatullah', Noorul Bashar ${ }^{2}$ \\ ${ }^{1} M$. Tech Student, Department of Civil Engineering, VCTM, Aligarh, AKTU Lucknow \\ ${ }^{2}$ Assistant Professor, Department of Civil Engineering, VCTM Aligarh, AKTU Lucknow
}

\begin{abstract}
Self-Compacting Concrete (SCC) represents one of the biggest modern innovations in the construction field worldwide. Until now, on an international level, the number of constructions using SCC as a main material is limited. Self-compacting concrete is a special type of concrete that is able to flow under its own weight, completely filling the formwork and consolidating without the need of vibration. Since its first development in Japan in 1980, SCC was widely accepted in Japan, Europe and USA due to its inherently distinct advantages. SCC provides better quality especially in the members improving durability of concrete and having reinforcement congestion or decreasing the permeability. In this presented post-graduate thesis, there is a complete report on mechanical properties and the major attributes of the fresh and hardened concrete, as well as on the methods of its production and the ingredients of the recycled materials. The primary research is to qualitatively and quantitatively explore the acceptability of destroyed concrete waste aggregate for the production of the SCC of high strength and desirable properties. It assesses experiments on various mixes of self-compacting concrete - one with the fresh coarse and fine aggregates, while the others with replacement of $15 \%, 30 \%, 40 \%$ and 50\% recycled coarse aggregates. Results in the experiments showed that the fresh, hardened and durability properties of all the concrete mixes were comparable. Wherein, the compressive strength of all the concrete mixes was measured at the age of 7 and 28days.

(C)2020 ijrei.com. All rights reserved
\end{abstract}

Keywords: Cement, Fine Aggregates, Coarse Aggregate, Water, Flyash, Admixture, Recycled Waste Concrete

\section{Introduction}

Construction is the backbone of infrastructural development and it derives its basic ingredients, which are sand and stone aggregate from nature. In the current scenario, the construction works is on boom, which leads to various environmental hazards such as

- The construction industry has ruined the ecological balance up to a great extent by taking away the natural stock of aggregates

- The heavy machinery involved to extract the stone aggregates from quarrying operates on fuels releasing obnoxious gases and fumes

- The air pollution from quarrying caused by release of suspended particulate matter into the atmosphere leads to danger for the working staff and the adjoining population
- The particulate matter from quarrying also runs off to the nearby rivers or water bodies, which pollute the water and destroy the aquatic life

- The required working quarry wants methods of transportation which means that the huge quantities of equipment and heavy traffic will be brought into the assignment area, ensuing into increase in local noise and air pollution.

- To facilitate the resistance from use of natural aggregates from the nature, various steps are continuously being taken by construction industry for infrastructure development. The recycled aggregates usage is one of the new steps in developing the concrete for the construction practices

- A simple mix Design method for self-compacting concrete" and the mix design of Self compacting concrete (M35) from Ambuja Cement. 
- Several changes were made through trials in the design to obtain the properties of self-compacting concrete.

- Initially the conventional self-compacting concrete was made and the fresh and hardened properties were checked.

- Proportion of $50 \%, 40 \%, 30 \%$ and $15 \%$ replacement of natural coarse aggregates were used in recycled coarse aggregates.

- Finally, there is comparison of the results of fresh and hardened properties for the conventional self-compacting concrete and the self-compacting concrete made from various proportions of replaced recycled coarse aggregates.

- Self-compacting concrete, also referred as selfconsolidating concrete, is the concrete that has ability to flow due to its own weight and completely fill the formwork, while maintaining homogeneity even in the availability of congested reinforcement, and then consolidating without the requirement of vibration.

- Conventional concrete requires external compaction work by internal or external vibrators for proper compaction, filling of the formwork and covering of the reinforcement. Proper SCC fulfills the same quality level but with no vibration. SCC compacts itself automatically by its own weight. In order to create the self- compacting effect of SCC, the friction between the particles has to be reduced at the same time as satisfying stability of the fresh concrete has to be maintained. In comparison with normal concrete of mechanical properties similar to SCC, the material cost of SCC is more due to the relatively high requirement of cementitious materials and chemical admixtures including high range water reducing admixtures (HRWRA) and viscosity modifying admixtures (VMA).

- However, the construction time of SCC is shorter and its production is environment friendly. Furthermore, SCC produces a good surface finish and gives greater freedom in design. These advantages make SCC particularly interesting for use in pre-casting plants, or surface repair.

\section{Experimentation Methodology}

The experimental research targets to compare the hardened properties of various mixes of SCC made from different proportions of recycled fine aggregates and conventional concrete. The basic materials used in making the Self Compacting followed by a brief description about mix design and curing procedure adopted. At the end various tests conducted on the specimens are discussed.

\subsection{Materials used for making SCC}

In this section brief description on physical properties of the material used to prepare SCC mixes is discussed. The ordinary Portland Cement of Grade 43 from Ambuja Cement Ltd. has been used for making the Self Compacting Concrete. Properties of Cement are tabulated below.

Generally, water that is suitable for drinking is satisfactory for use in concrete. Class F Fly ash obtained from Harduaganj Thermal Power Plant, Aligarh (U.P.) was used.

Table 1: Physical properties of Cement

\begin{tabular}{|c|c|c|c|}
\hline Properties & \multicolumn{3}{|c|}{ Ordinary Portland Cement } \\
\hline Specific Gravity & \multicolumn{3}{|c|}{2.2} \\
\hline Initial Setting Time & \multicolumn{3}{|c|}{180 Minutes } \\
\hline Final Setting Time & \multicolumn{3}{|c|}{10 Hours } \\
\hline $\begin{array}{c}\text { Compressive Strength of } \\
\text { mortar cubes (Conforming } \\
\text { to IS:4031 part-6-1988) }\end{array}$ & 3 day & 7 day & 28 day \\
\cline { 2 - 4 } & $28.71 \mathrm{MPa}$ & $37.8 \mathrm{MPa}$ & $42.6 \mathrm{MPa}$ \\
\hline
\end{tabular}

\subsection{Fine Aggregates}

The natural fine aggregates were procured from Kotputli source. The Properties of the natural fine aggregate used in the experimental work are tabulated in Table 2.

Table 2: Properties of the natural fine aggregate

\begin{tabular}{|r|c|c|}
\hline S.No & Characteristics & Value \\
\hline 1 & Specific gravity & 2.50 \\
\hline 2 & Bulk Density & $1,925 \mathrm{Kg} / \mathrm{m}^{3}$ \\
\hline 3 & Water Absorption & $0.83 \%$ \\
\hline
\end{tabular}

\subsection{Coarse aggregate}

Crushed stone is generally used as a coarse aggregate. Locally available coarse aggregate having the maximum size of 10 to $20 \mathrm{~mm}$ was used in our work. The aggregates were tested as per IS: 383-1970.

The results of different tests performed on the coarse aggregates are shown and recycles coarse aggregate were obtaining from demolished structure and their properties and their sieve analysis results show in table 3.

Table 3: Physical properties of coarse aggregate

\begin{tabular}{|c|c|c|}
\hline Sr. No & Characteristics & Value \\
\hline 1 & Type & Crushed \\
\hline 2 & Specific Gravity & 2.6 \\
\hline 3 & Total Water Absorption & 0.55 \\
\hline 4 & Fineness Modulus & 6.41 \\
\hline
\end{tabular}

Table 4: Sieve analysis of recycle coarse aggregate

\begin{tabular}{|c|c|c|c|c|c|}
\hline S.N & $\begin{array}{c}\text { Sieve } \\
\text { Size }\end{array}$ & $\begin{array}{c}\text { Mass } \\
\text { Retained } \\
(\mathrm{gm})\end{array}$ & $\begin{array}{c}\text { Percentage } \\
\text { retained }\end{array}$ & $\begin{array}{c}\text { Cumulative } \\
\text { Percentage } \\
\text { retained }\end{array}$ & $\begin{array}{c}\text { Percent } \\
\text { Passing }\end{array}$ \\
\hline 1 & $20 \mathrm{~mm}$ & 0 & 0 & 0 & 100 \\
\hline 2 & $10 \mathrm{~mm}$ & 2502 & 83.4 & 83.4 & 16.6 \\
\hline 3 & $4.75 \mathrm{~mm}$ & 468 & 15.6 & 99 & 1 \\
\hline 4 & PAN & 12 & 0.4 & $\Sigma=182.4$ & \\
\hline
\end{tabular}




\subsection{Admixture}

Admixture used in this work is Superplasticizer of CICO brand, which complies with IS: 9103:1979 and BS: 5075 Part 3 and ASTM-C-494 type ' $F$ ' as a high range water reducing admixture. At the time of batching, Ultracon SP 430 is ready to use admixture which is mixed to the concrete. Ultracon SP430 is differentiated from conventional superplasticizers due to the fact that it is based on aqueous solution of lignosulphonates and organic polymer with long lateral chains. This greatly enhances the cement dispersion. Ultracon SP430 is brought as brown liquid which is instantly dispersible in water and also specially formulated to give high water reduction up to $25 \%$ without any loss of workability. Specific gravity is 1.22 to 1.225 at $30^{\circ} \mathrm{C}$.

\subsection{Mix Design}

The base mix was designed for M35 concrete according to the guidelines given in IS: 102622009 (code of practice for mix design of normal concrete) and several changes were made through trials in the design to obtain the properties of selfcompacting concrete. Changes include:

- Increase in the quantity of powder content (particle size $<150 \mu)$.

- Optimal dosage of super plasticizer.

Initially two types of SCC were prepared- one completely with fresh coarse and fine aggregate and other with fresh fine aggregate and $100 \%$ replacement of fresh coarse aggregate with recycle done. The w/c and water to binder ratio of the base mix was kept as 0.45 and 0.35 respectively. However, slight modifications in the water quantity were introduced on the spot to achieve the desired workability, flow ability and to account for more water absorption of recycled fine aggregates than fresh ones. The intermediate mix designs with the replacement of $15 \%, 30 \%$ and $40 \%$ of recycled coarse aggregates were prepared for the comparison of fresh and hardened properties.

\section{Results and discussion}

This section comprises of the results for the fresh and hardened properties of various mixtures for making self-compacting concrete made from different proportions of recycled coarse aggregates. s The results of fresh properties of all Selfcompacting concretes are included. The Table shows the properties such as slump flow, V-funnel flow times, L-box and U- box. SCC prepared with the recycled coarse aggregates and natural fine aggregate requires more water than the conventional SCC in order to obtain the same workability.

\subsection{Hardened Properties}

\subsubsection{Compressive Strength}

The compressive strength tests result of self-compacting Concrete are given. As the percentage of recycled coarse aggregates increases, the compressive strength of the SCC decreases.

Table 5- Fresh concrete properties

\begin{tabular}{|c|c|c|c|c|c|c|c|c|}
\hline \multirow[b]{2}{*}{ 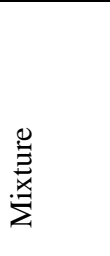 } & \multicolumn{2}{|c|}{ Slump (mm) } & \multicolumn{2}{|c|}{$\begin{array}{l}\text { V-Funnel } \\
\text { (Seconds) }\end{array}$} & \multicolumn{2}{|c|}{$\begin{array}{c}\text { L-Box } \\
\text { (H2/H1) }\end{array}$} & \multicolumn{2}{|c|}{$\begin{array}{c}\text { U-Box (H2- } \\
\text { H1) mm }\end{array}$} \\
\hline & 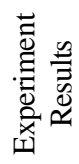 & 案 & 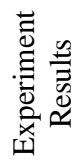 & 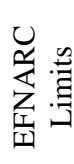 & 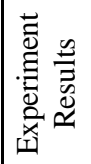 & 空 & 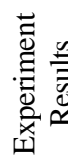 & 焉莟 \\
\hline SCC-C & 750 & $650-800$ & 7 & $6-12$ & 0.90 & $0.8-1$ & 27 & $0-30$ \\
\hline RCA15 & 710 & $650-800$ & 8 & $6-12$ & 0.88 & $0.8-1$ & 25 & $0-30$ \\
\hline RCA30 & 685 & $650-800$ & 9 & $6-12$ & 0.84 & $0.8-1$ & 23 & $0-30$ \\
\hline RCA40 & 660 & $650-800$ & 10.5 & $6-12$ & 0.832 & $0.8-1$ & 20 & $0-30$ \\
\hline RCA50 & 630 & $650-800$ & 12 & $6-12$ & 0.77 & $0.8-1$ & 15 & $0-30$ \\
\hline
\end{tabular}

Table 6- Compressive Strength Test Results

\begin{tabular}{|c|c|c|c|c|}
\hline \multirow{2}{*}{ Mix } & \multicolumn{2}{|c|}{$\begin{array}{c}\text { Compressive Strength } \\
\left(\mathrm{N} / \mathrm{mm}^{2}\right)\end{array}$} & \multicolumn{2}{|c|}{$\begin{array}{c}\text { Average } \\
\text { Compressive }\end{array}$} \\
\hline & 7 days & 28 days & 7 days & 28 days \\
\hline \multirow{3}{*}{$\begin{array}{c}\text { Conventional } \\
\text { SCC }\end{array}$} & 36.5 & 58.1 & \multirow{3}{*}{37.8} & \multirow{3}{*}{58.6} \\
\hline & 41.2 & 60.7 & & \\
\hline & 35.8 & 57.1 & & \\
\hline \multirow{3}{*}{ RCA 15} & 33.4 & 53.4 & \multirow{3}{*}{36.3} & \multirow{3}{*}{55.9} \\
\hline & 39 & 56.5 & & \\
\hline & 36.7 & 57.9 & & \\
\hline \multirow{3}{*}{ RCA 30} & 31.2 & 51.4 & \multirow{3}{*}{32.5} & \multirow{3}{*}{49.5} \\
\hline & 35.5 & 48.1 & & \\
\hline & 30.8 & 49 & & \\
\hline \multirow{3}{*}{ RCA 40} & 25.2 & 43.1 & \multirow{3}{*}{24.5} & \multirow{3}{*}{45} \\
\hline & 27.8 & 46.7 & & \\
\hline & 20.7 & 45.3 & & \\
\hline \multirow{3}{*}{ RCA 50} & 26.3 & 41.6 & \multirow{3}{*}{24.3} & \multirow{3}{*}{43.7} \\
\hline & 22.1 & 45.7 & & \\
\hline & 24.6 & 44 & & \\
\hline
\end{tabular}




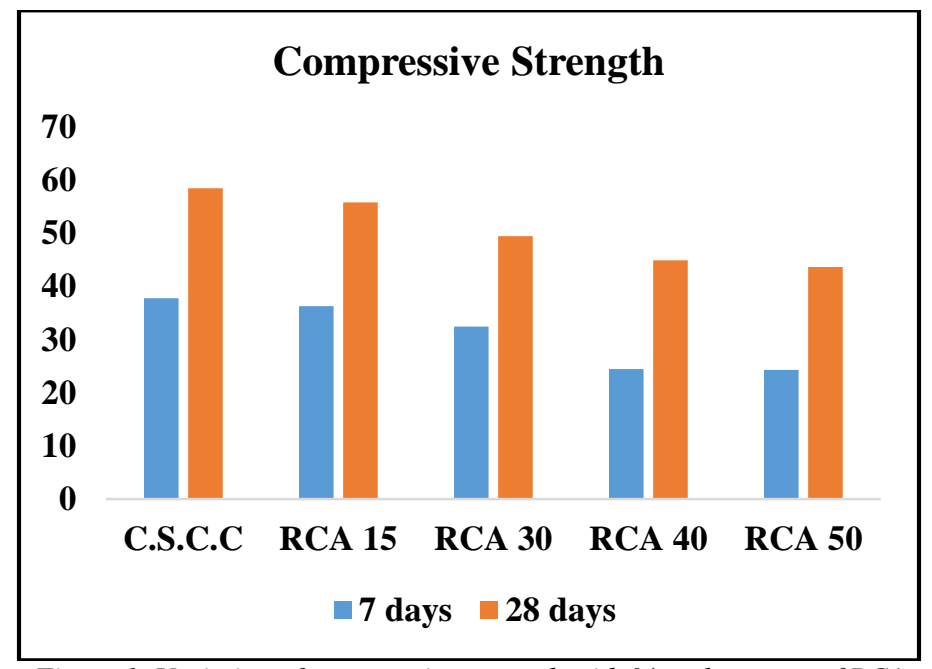

Figure 1- Variation of compressive strength with \% replacement of RCA

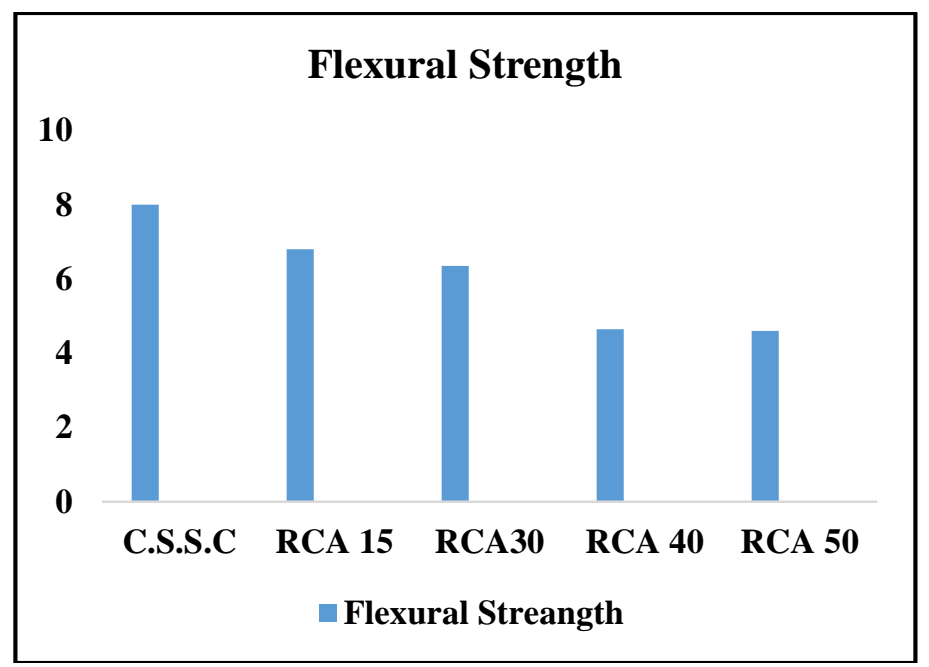

Figure 2- Variation offlexural strength with \% replacement of RCA

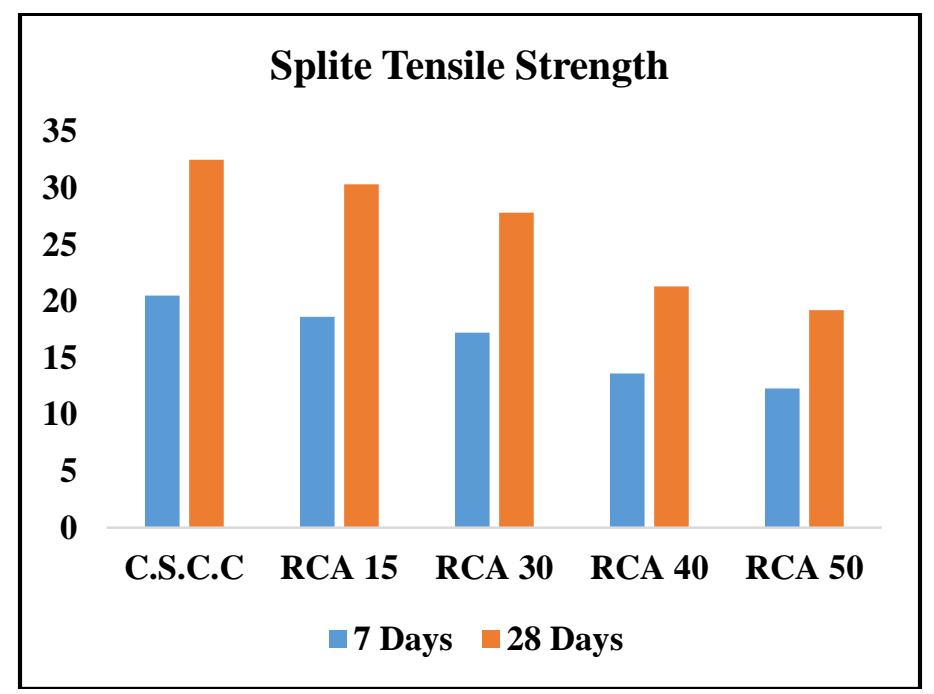

Figure 3- Variation of split tensile strength with \% replacement of RFA

\section{Water Absorption}

5

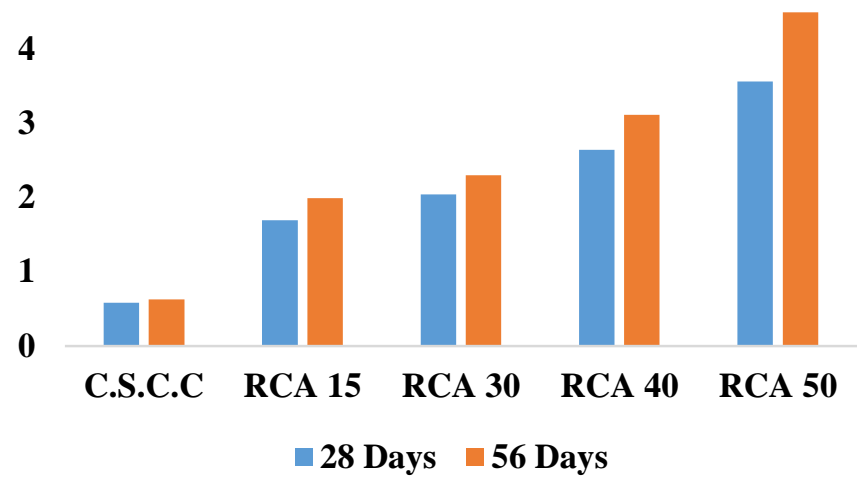

Figure 4- Percentage of water absorbed at various ages

\section{Conclusions and Future scope}

\subsection{Fresh SCC Properties}

- The current research shows that SCC prepared from recycled coarse aggregates (RCA) provides satisfied workability requirements as per the desired limits for acceptance.

- The slump flow test gives the readings from $650 \mathrm{~mm}$ to $750 \mathrm{~mm}$, the V-funnel time gives the readings from 7 seconds to 12 seconds, the L-box test value ranges between $0.77 \& 0.9$ and the U-box test result shows the value between $15 \mathrm{~mm}$ to $30 \mathrm{~mm}$.

- Slump test, V-funnel test, L-box test and the U-box test values all fall in the range of EFNARC limits.

- It justifies the replacement or use of RCA in SCC. Hence, recycled fine aggregates can be used for the preparation of SCC.

- In general, as the SCC is made by replacing fresh aggregates with RCA, fall in initial as well as final compressive strengths is observed.

- It is due to the reason that as the replacement of CA with RCA increases, the microstructure becomes more porous, water requirement and absorption increases and hence, drop in compressive strengths is observed.

- 28 days' compressive strength of conventional SCC was found to be $58.6 \mathrm{~N} / \mathrm{mm}^{2}$, whereas the 28 days' compressive strength decreases to $43.7 \mathrm{~N} / \mathrm{mm}^{2}$ as the coarse aggregates were replaced by $50 \%$ recycled coarse aggregates.

- 7 days' compressive strength of SCC shows that there is a little more variation in result when replacement is increased from $0 \%$ to $50 \%$ of recycled coarse aggregates. The percentage drop in strengths is observed as $4.4 \%$, $13.9 \%, 35 \%$ and $35.8 \%$ for $15 \%, 30 \%, 40 \%$ and $50 \%$ replacement of recycled coarse aggregates respectively. 
- With the percentage replacement of $15 \%$ of recycled coarse aggregates, the 28 days compressive strength decreases by a small value of $5.1 \%$, with replacement of $30 \%$ of recycled coarse aggregates, the 28 days compressive strength decreases to $15.4 \%$, with replacement of $40 \%$ of recycled coarse aggregates, the 28 days compressive strength decreases to $23.12 \%$ and with replacement of $50 \%$ of recycled coarse aggregates, the 28 days compressive strength decreases to $25.85 \%$.

- It was concluded that, for the replacement of recycled coarse aggregates up to $15 \%$, the decrease in compressive strength is very low as compared to the replacement of recycled coarse aggregates by $30 \%, 40 \%$ and $50 \%$.

- Therefore, it is justified from the results to replace CA with RCA up to $15-30 \%$ for the perspective of cost reduction and waste management.

\subsection{Flexural Strength}

- As the percentage of recycled coarse aggregates increases, the flexural strength of the SCC decreases. The 28 days' flexural strength of conventional SCC was found to be 8.0 $\mathrm{N} / \mathrm{mm}^{2}$, whereas the 28 days' flexural strength decreases to $4.6 \mathrm{~N} / \mathrm{mm}^{2}$.

- While replacing recycled coarse aggregates from $0 \%$ to $50 \%$, The 28 days' flexural strength decreases. The percentage decreases are $16.4 \%, 21.4 \%, 42.6 \%$ and $43.89 \%$ for $15 \%, 30 \%, 40 \%$ and $50 \%$ replacement of recycled coarse aggregates respectively.

\subsection{Split Tensile Strength}

- With the percentage replacement of $15 \%$ of recycled coarse aggregates, the 28 days compressive strength decreases by a small percentage of $6.7 \%$, with replacement of $30 \%$ of recycled coarse aggregates, the 28 days compressive strength decreases to $14.46 \%$.

- $\%$, with replacement of $40 \%$ of recycled coarse aggregates, the 28 days compressive strength decreases to $34.35 \%$ and with replacement of $50 \%$ of recycled coarse aggregates, the 28 days compressive strength decreases to $40.7 \%$.

- The 7 days split tensile strength shows the decreases in strength from $20.5 \mathrm{~N} / \mathrm{mm}^{2}$ to $12.3 \mathrm{~N} / \mathrm{mm}^{2}$ as the percentage of recycled coarse aggregates increases in the mixes of SCC.

\subsection{Durability Properties}

- From data of the results of water absorption, it is observed that the water absorption values of SCC containing the RCA are higher than that of the conventional SCC.

- The SCC made with 50\% RCA shows 6.3 times higher absorption which is higher than conventional SCC at the age of 28 days and 7.2 times higher than conventional SCC at the age of 56 days, which means water absorption values of all the RCA- SCC were higher than the conventional SCC.

- The absorption increased with an increase in percentage of RCA. It was due to the high absorption capacity of the RCA itself, which has created higher osmosis pressure within the concrete.

\subsection{Overall Conclusions}

- Further, the fresh properties for the SCC made with recycled Coarse aggregates gives satisfactory results for their use in SCC.

- The hardened and durability characteristics of modified SCC with replacement of CA with RCA variably shows marginal decrease in strengths as well as durability characteristics.

- $0 \%$ to $30 \%$ replacement of RCA to modify SCC, it shows very small marginal fall in compressive, flexural as well as split tensile strength values as compared to conventional SCC.

- $\quad$ Some admixture like silicafume, alccofine, etc. can be used to retrieve the loss in strengths.

- But the falls in strengths and durability parameters is not so large and hence, it justifies the use of waste fine aggregates in SCC from environmental and waste management issues.

\subsection{Further scope of work}

- Detailed investigation on optimal replacement of RCA in SCC without compromising on strength and durability.

- Study on the use of admixtures like alccofine, silica fumes, nano silica etc. can be made in SCC modified by waste concrete aggregates to improve the strength and durability.

\section{References}

[1] K., Maekawa K., Kunishima M., Okamura H., "Development of high performance concrete based on the durability design of concrete structures", East Asia and Pacific Conference on Structural Engineering and Construction (EASEC-2) 1989, vol.1, pp 445-450.

[2] Okamura H., and Ouchi M., "Self-compacting concrete-development, present and future", Proceeding of the First International RILEM symposium on SelfCompacting Concrete, 1999.

[3] Ouchi M., Hibino M., Sugamata T., and Okamura H., "A quantitative evaluation method for the effect of superplasticizer in self-compacting concrete", Transactions of JCI, 2001, pp 15-20.

[4] Bui V.K., Montgomery D., Hinczak I. and Tumer K., "Rapid testing method for segregation resistance of self-compacting concrete", Cement and Concrete Research, 2002, vol.32, pp 1489-1496.

[5] Alexander C. and Prosk., (2003) "Self-Compacting Concrete-Influence of the Coarse Aggregate on The fresh Concrete Properties" http://www.darmstadtconcrete.de, pp. 1-4.

[6] Bui V.K., Akkaya Y. and Shah S.P., (2002) "Rheological Model for Self-Consolidating concrete". American Concrete Institute 99 (2002) 549-559.

[7] Domone P.L., (2005) "Self-compacting concrete: An analysis of 11 years case studies". Cement \& Concrete Composites 28 (2006) 197-208. 
[8] Debs E.L., Casas J.R., Barragan B.E. and Filho F.M., (2008) "Variability of bond and mechanical properties of Self Compacting Concrete". Ibracon Structures and Material Journal (2008) 1983-4195.

[9] EFNARC 2002,, "Specification and Guidelines for Self-Compacting Concrete", page- 32, www.efnarce.org.

[10] Felekoglu B., Turkel S. and Baradan B., (2006) "Effect of water/cement ratio on the fresh and hardened properties of self-compacting concrete". Building and Environment 42 (2007) 1795- 1802.

[11] Grdic Z. J., Gordana A., Curcic T., Despotovic I.M. and Ristic N.S., (2010) “Properties of self-compacting

[12] concrete prepared with coarse recycled concrete aggregate". Construction and Building Materials 24 (2010) $1129-1133$.

[13] Khaleel O.R., Al-Mishhadani S.A. and Razak H.A., (2011) "The Effect of Coarse Aggregates on Fresh and Hardened Properties of Self-Compacting Concrete (SCC)". Procedia Engineering 14 (2011)805-813.

[14] Kou S.C. and Poon C.S., (2009)" Properties of self-compacting concrete prepared with coarse and fine recycled concrete aggregates". Cement \& Concrete Composites 31 (2009) 622-627.

[15] Okamura H. and Ouchi M., (2003) "Self-Compacting Concrete." Journal of
Advanced Concrete Technology, Vol. 1 (1), (2003)5-15.

[16] Pereira P., Evangelista L. and Brito J., (2012) "The effect of superplasticizers on the mechanical performance of concrete made with fine recycled concrete aggregates". Cement \& Concrete Composites xxx (2012) xxx-xxx, Elsevier Ltd.

[17] Parra C., Valcuende M. and Gomez F. (2010) "Splitting tensile strength and modulus of elasticity of self-compacting concrete." Construction and Building Materials 25 (2011) 201-207.

[18] Petersson O., (1997) "Preliminary Mix Design" Final Report of Task 1, Swedish Cement and Concrete Research Institute, pp.15-19.

[19] Safiuddin M.D., Salam M.A. and Jumaat M.Z., (2011) "Effects of recycled concrete aggregate on the fresh properties of self-consolidating concrete". Archives of Civil and Mechanical Engineering, Volume XI (2011) 1023 - 1041.

[20] Siddique R., (2010) 'Properties of self-compacting concrete containing class F fly ash". Material and Design 32 (2011) $1501-1507$.

[21] Sahmaran M., Yaman O. and Tokyay M., (2009) "Transport and mechanical properties of self-consolidating concrete with high volume fly ash". Cement and Concrete Composites Volume 31, Issue 2, February 2009, Pages99-106.

Cite this article as: Mohd Aiyatullah, Noorul Bashar, Study of self-compacting concrete using recycled waste concrete as coarse aggregate, International Journal of Research in Engineering and Innovation Vol-4, Issue-4 (2020), 212-217.

https://doi.org/10.36037/IJREI.2020.4405. 